УДК 663.11+663.43

\title{
ДИНАМИКА АЗОТИСТЫХ ВЕЩЕСТВ В ПРОЦЕССЕ СОЛОДОРАЩЕНИЯ ЗЕРНА ПШЕНИЦЫ С РАЗЛИЧНЫМ СОДЕРЖАНИЕМ БЕЛКА
}

\author{
(C) М.Ф. Ростовская", Н.Н. Извекова, Б.А. Алябьев, Ю.В. Приходько
}

\author{
Дальневосточный федеральный университет, Школа биомедицины, \\ ул. Суханова, 8, Владивосток, 690950 (Россия), e-mail: rost-mf@mail.ru
}

\begin{abstract}
Исследовано изменение содержания азотистых веществ в процессе солодоращения зерна двух сортов яровой пшеницы (Triticum aestivum L.), выращиваемых в Приморском крае и отличающихся уровнем белковых веществ в зерне. Показано, что при проращивании зерно с повышенным содержанием белка передает больше азотистых веществ в корни и ростки, и таким образом наблюдается более значительная потеря азотистых веществ в эндосперме и зародыше. Но удлинение сроков проращивания приводит к уменьшению массы зерна за счет потерь на дыхание, что способствует увеличению концентрации азотистых веществ в зерне.

Ключевые слова: пшеница, проращивание, азотистые вещества, содержание белка, солод.
\end{abstract}

\section{Введение}

Традиционное сырье для получения пива - ячменный солод. Но в пивоварении используют и пшеницу. Из пшеницы получают пшеничный солод, который применяют для получения пива верхового брожения Weizendier и Weissbier [1]. Пшеницу и пшеничный солод также используют в качестве добавки к ячменному солоду (3-10\%) в пивной индустрии для увеличения выхода экстракта и получения более стабильной пены [2]. Кроме того, небольшие количества пшеничного солода увеличивают диастатическую силу засыпи [3].

У зерна и ячменя, и пшеницы, предназначенного для солодоращения, желательна низкая концентрация белковых веществ в зерне. Высокий уровень белка снижает выход экстракта солода и затрудняет его переработку [4]. Также высокий уровень белка приводит к уплотнению белково-крахмального комплекса, что ограничивает гидратацию эндосперма во время проращивания и замедляет преобразование эндосперма и образование ферментов [5]. Кроме того, пшеничный солод, по сравнению с ячменным, увеличивает интенсивность помутнений в пиве из-за протеолиза пшеничного белка глютеина [6]. И у пшеницы, и у ячменя, предназначенного для солодоращения, значение уровня белка не должно превышать $12 \%$ [4, 7]. При этом на пивоваренный ячмень имеется ГОСТ [7], а специальных сортов пивоваренной пшеницы не существует.

Но в последние годы многие страны - поставщики пивоваренного зерна - столкнулись с проблемой вы-

Ростовская Марина Феликсовна - доцент кафедры продуктов питания из растительного сырья, кандидат химичеких наук, тел.: (423) 240-65-69,

e-mail: rost-mf@mail.ru

Извекова Анастасия Николаевна - студентка

Алябьев Борис Александрович - аспирант кафедры продуктов питания из растительного сырья, e-mail:sopka2008@mail.ru

Приходько Юрий Вадимович - заведующий кафедрой продуктов питания из растительного сырья, доктор технических наук, тел.: (423) 240-65-69, e-mail:Yu_prihodko@hotmail.com сокобелковистого зерна [8]. Поэтому в разных странах проводятся исследования по получению солода удовлетворительного качества из зерна ячменя и пшеницы с повышенным содержанием белка. В работе [9] показано, что канадские сорта ячменя с содержанием белка $16,4 \%$ способны давать солод и пиво хорошего качества. Традиционные сорта пшеницы, выращиваемые в Китае, имеют уровень белка 16\%. В работе [10] установлено, что из такой пшеницы возможно производить солод удовлетворительного качества.

\footnotetext{
* Автор, с которым следует вести переписку.
} 
Солод получают контролируемым проращиванием зерна. После высушивания свежепроросшего солода корни и ростки удаляются. Известно, что корни и ростки проращиваемого зерна богаты гидролизуемыми белками, поэтому через корни и ростки могут происходить высокие потери белков [11]. Пшеница, в отличие от ячменя, не имеет цветочной оболочки, поэтому росток, который у ячменя находится внутри оболочки и остается в сухом солоде, у пшеницы удаляется после высушивания вместе с содержащимися в нем азотистыми веществами, что уменьшает содержание азотистых веществ в пшеничном солоде более значительно, по сравнению с ячменем. Ранее нами показано, что солод, полученный из зерна пшеницы с большим содержанием белка, может иметь меньший уровень белка, по сравнению с солодом, полученным из менее белковистого зерна [12].

Мониторинг белковых веществ во время проращивания зерна пшеницы может быть полезен для оптимизации процесса солодоращения и улучшения характеристик пшеничного солода.

Цель работы - проследить изменение содержания азотистых веществ в процессе солодоращения пшеницы с разным уровнем белковых веществ в зерне и оценить потери азотистых веществ через корни и ростки.

\section{Экспериментальная часть}

Для исследования использовали два районированных сорта яровой мягкой пшеницы (Triticum aestivum L. ) дальневосточной селекции урожая 2010 г. - Приморская 39, Приморская 40, отличающихся уровнем содержания белка. Образцы выращивались в одном и том же месте и одних и тех же погодных условиях. Все сорта пшеницы получены в ПримНИИСХ, п. Тимирязевский.

Анализ зерна проводили по стандартным методикам, определяя массу 1000 зерен (ГОСТ 10842-89), энергию и способность прорастания (ГОСТ 10968-88), содержание влаги (ГОСТ 13586.5-93). Массовую долю белка измеряли по методу Кьельдаля (ГОСТ 10846-76), массовую долю крахмала - поляриметрическим методом, определяя количество оптически активных сахаров, образовавшихся после гидролиза крахмала (ГОСТ 10845-76).

Зерно обоих сортов подвергали проращиванию в одинаковых условиях при убывающих температуpax от 19 до $15{ }^{\circ} \mathrm{C}$. Проращивание зерна проводили в хладотермостате XT-3/70-2. Общее время солодоращения составило 91 ч. После этого часть солода сушили в сушильном шкафу Binder FD-2, получая сухой солод, а оставшуюся часть продолжали проращивать до общего времени проращивания 167 ч. В процессе солодоращения ежедневно отбирали пробы зерна и измеряли содержание влаги, используя влагомер «Элвиз 2», а также ежедневно отбирали параллели по 100 зерен, определяли их массу в нативном зерне, в зерне с удаленными корнями и ростками и в удаленных корнях и ростках, используя аналитические весы ACOM JW-1. Потери на корни и ростки определяли по формуле [10]: $\mathrm{M}_{\mathrm{\kappa}+\mathrm{p}} \%=\mathrm{M}_{3} \cdot 100 / \mathrm{M}_{1}$, где $\mathrm{M}_{1}-$ масса 100 зерен с корнями (СВ - на сухое вещество) в момент солодоращения; $\mathrm{M}_{2}$ - масса 100 зерен без корней и ростков (СВ) в момент солодоращения; $\mathrm{M}_{3}$ - масса корней и ростков $(\mathrm{CB})$ в момент солодоращения; $\mathrm{M}_{3}=\mathrm{M}_{1}-\mathrm{M}_{2}$. Потери на дыхание определяли по формуле $\mathrm{M}_{д} \%=\mathrm{M}_{0}-\mathrm{M}_{1} \cdot 100 / \mathrm{M}_{0}$, где $\mathrm{M}_{0}$ - масса 100 зерен (CВ) до начала солодоращения. В процессе солодоращения ежедневно определяли содержание белковых веществ методом Кьельдаля (ГОСТ 10846-76) в нативном зерне, в зерне с удаленными корнями и ростками и в удаленных корнях и ростках, а также содержание свободного аминного азота нингидриновым методом (Еuropean Brewing Convention Analytic, method 4.10, 1998).

Статистическую обработку вели с использованием пакета стандартных программ.

\section{Обсуждение результатов}

Показатели зерна представлены в таблице 1, из которой видно, что сорт Приморская 40 имел более высокий уровень белковых веществ, разница в уровне белка исследуемых сортов составляла около $2 \%$. Оба сорта имели отличную энергию прорастания и обладали важным критерием для зерна, предназначенного для солодоращения.

Оба сорта подвергли солодоращению в одинаковых условиях. Вначале зерно замачивали, затем проращивали на воздухе, периодически орошая. Ежедневно в зерне измеряли содержание влаги и определяли массу 100 зерен в нативном зерне, в зерне с удаленными корнями и ростками и в удаленных корнях и ростках. Формулы для расчета потерь на корни и ростки, а также на дыхание приведены в экспериментальной части.

Потери от корней и ростков в процессе солодоращения представлены в таблице 2. 
Таблица 1. Показатели зерна пшеницы

\begin{tabular}{l|c|c}
\hline \multicolumn{1}{c|}{ Показатель } & Приморская 39 & Приморская 40 \\
\hline Масса 1000 зерен, г & $32,16 \pm 0,12$ & $41,38 \pm 0,07$ \\
Энергия прорастания, \% & $98,2 \pm 0,4$ & $98,7 \pm 0,1$ \\
Способность прорастания,\% & $98,6 \pm 0,2$ & $99,0 \pm 0,1$ \\
Содержание влаги, \% & $8,3 \pm 0,05$ & $10,3 \pm 0,07$ \\
Массовая доля белка, \%, СB ${ }^{1}$ & $13,16 \pm 0,47$ & $15,31 \pm 0,31$ \\
Массовая доля крахмала, \%, СВ & $64,11 \pm 0,38$ & $63,62 \pm 0,25$ \\
Диастатическая сила $\mathrm{WK}^{2}, \mathrm{CB}$ & $62,8 \pm 2,2$ & $55,1 \pm 3,3$ \\
\hline
\end{tabular}

Примечание: ${ }^{1} \mathrm{CB}$ - сухое вещество; ${ }^{2} \mathrm{WK}$ - единицы Виндиш - Кольбаха.

Таблица 2. Потери от корней и ростков в процессе солодоращения, \%

\begin{tabular}{c|c|c|c|c}
\hline \multirow{2}{*}{$\begin{array}{c}\text { Время от начала } \\
\text { солодоращения, ч }\end{array}$} & \multicolumn{2}{|c|}{ Приморская 39 } & \multicolumn{2}{|c}{ Приморская 40 } \\
\cline { 2 - 5 } & $\begin{array}{c}\text { потери на корни } \\
\text { и ростки }\end{array}$ & $\begin{array}{c}\text { потери } \\
\text { на дыхание }\end{array}$ & $\begin{array}{c}\text { потери на корни } \\
\text { и ростки }\end{array}$ & $\begin{array}{c}\text { потери } \\
\text { на дыхание }\end{array}$ \\
\hline 0 & - & - & - & - \\
25 & - & - & 6,4 & 2,2 \\
46 & 4,5 & 1,8 & 14,3 & 4,8 \\
72 & 12,3 & 3,5 & 19,5 & 5,2 \\
\hline
\end{tabular}

В первые сутки проращивания корней и ростков практически не было, они появились на вторые сутки. Но с появлением корней и ростков проявилась разница: зерно сорта Приморская 40 прорастало более энергично, соответственно потери массы на корни и ростки были выше, хотя образцы солодились при одинаковых условиях. Потери на корни и ростки при проращивании пшеницы оказались более высокими по сравнению с ячменем [13].

Потери массы на дыхание у пшеницы сорта Приморская 40 также оказались выше, чем у сорта Приморская 39. Потери массы на дыхание у пшеницы во время проращивания сравнимы с потерями дыхания ячменя [13].

Динамика азотистых веществ в зерне пшеницы с разным содержанием белка в процессе солодоращения показана в таблице 3.

Из таблицы 3 следует, что общее содержание азотистых веществ в зерне в процессе солодоращения изменяется. При получении солода зерно вначале замачивают, затем проращивают на воздухе, периодически орошая. В зерне обоих сортов вначале наблюдается уменьшение азотистых веществ, затем их количество возрастает. Считается, что потеря азотистых веществ происходит при выщелачивании во время замачивания. Во время дальнейшего проращивания на воздухе потери на дыхание вызывают снижение массы зерна, таким образом, увеличивая относительное содержание азотистых веществ в пересчете на сухое вещество [13].

В нашем случае зерно сорта Приморская 40, изначально содержащее более высокий уровень белка, в процессе замачивания теряло больше азотистых веществ, чем зерно сорта Приморская 39 (3,7\% против 1,2\% в пересчете на белок). В то же время зерно Приморская 40 теряло больше массы в процессе дыхания (табл. 2), восстанавливая содержание азотистых веществ в большей степени.

В ходе солодоращения в зерне протекают два процесса - гидролиз и синтез белков. В процессе проращивания зерна часть белков подвергается воздействию протеолитических ферментов и гидролизуется до пептидов и аминокислот, из которых зародыш строит новые белки, входящие в состав новых тканей [4, 14]. Протеолиз белков можно оценить по величине свободного аминного азота. С увеличением деградации белков величина свободного аминного азота увеличивается [15].

Изменение количества свободного аминного азота в процессе солодоращения представлено в таблице 4. Из полученных данных видно, что в процессе солодоращения величина свободного аминного азота непрерывно возрастает из-за увеличивающегося распада белков, как ранее было показано для ячменя [11] и пшеницы [15]. Но в нашем случае пшеница с более высоким содержанием белка в процессе проращивания все время имела более низкий уровень свободного аминного азота, чем пшеница с более низким содержанием белка. Эти данные не совпадают с данными, представленными в работе [11], посвященной исследованию ячменя, где ячмень с более высоким уровнем белка производил больше свободного аминного азота. С другой стороны, в работе [10], посвященной исследованию пшеницы, не было получено однозначных данных между уровнем белка в зерне и величиной свободного аминного азота. 
Таблица 3. Изменение уровня азотистых веществ (в пересчете на белок) в зерне пшеницы в процессе солодоращения

\begin{tabular}{|c|c|c|c|c|c|c|c|}
\hline \multicolumn{4}{|c|}{ Приморская 39} & \multicolumn{4}{|c|}{ Приморская 40} \\
\hline 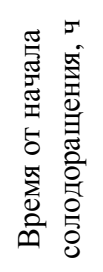 & 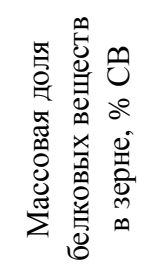 & 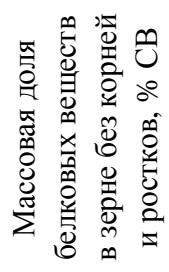 & 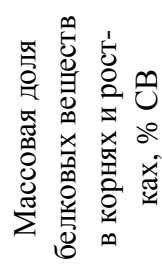 & 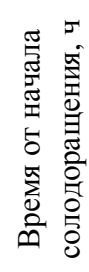 & 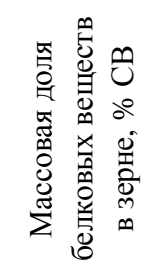 & 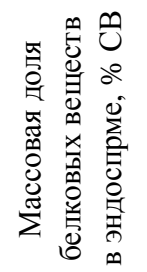 & 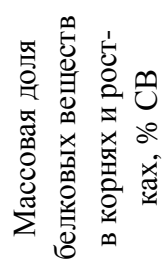 \\
\hline 0 & $13,16 \pm 0,47$ & & & 0 & $15,31 \pm 0,31$ & & \\
\hline 25 & $13,82 \pm 0,33$ & & & 25 & $15,53 \pm 0,37$ & & \\
\hline 46 & $13,79 \pm 0,39$ & $14,1 \pm 0,41$ & $7,2 \pm 0,25$ & 46 & $12,82 \pm 0,41$ & $14,8 \pm 0,38$ & $11,0 \pm 0,44$ \\
\hline 73 & $12,62 \pm 0,34$ & $13,0 \pm 0,27$ & $7,6 \pm 0,32$ & 69 & $12,11 \pm 0,28$ & $14,1 \pm 0,33$ & $11,6 \pm 0,33$ \\
\hline 91 & $13,53 \pm 0,24$ & $12,7 \pm 0,32$ & $8,9 \pm 0,38$ & 91 & $14,78 \pm 0,25$ & $13,8 \pm 0,37$ & $14,1 \pm 0,37$ \\
\hline 118 & $15,11 \pm 0,36$ & $14,7 \pm 0,39$ & $12,6 \pm 0,42$ & - & - & - & - \\
\hline
\end{tabular}

Таблица 4. Изменение уровня свободного аминного азота в процессе солодоращения

\begin{tabular}{c|c|c|c}
\hline \multicolumn{2}{c|}{ Приморская 39 } & \multicolumn{2}{c}{ Приморская 40 } \\
\hline $\begin{array}{c}\text { Время от начала } \\
\text { солодоращения, ч }\end{array}$ & $\begin{array}{c}\text { Содержание свободного } \\
\text { аминного азота, мг/100г, СВ }\end{array}$ & $\begin{array}{c}\text { Время от начала } \\
\text { солодоращения, ч }\end{array}$ & $\begin{array}{c}\text { Содержание свободного } \\
\text { аминного азота, мг/100г, СВ }\end{array}$ \\
\hline 0 & $15,9 \pm 0,31$ & 0 & $13,5 \pm 0,42$ \\
19 & $27,2 \pm 0,10$ & 23 & $21,1 \pm 0,37$ \\
43 & $49,5 \pm 0,06$ & 42 & $40,1 \pm 0,50$ \\
67 & $102,9 \pm 0,21$ & 71,5 & $75,0 \pm 0,52$ \\
91 & $139,6 \pm 0,05$ & 91 & $121,4 \pm 0,32$ \\
\hline
\end{tabular}

Корешки с ростками у проращиваемого зерна появились на вторые сутки. Начиная с этого времени содержание азотистых веществ определяли отдельно в зерне без корней и ростков, отдельно в корнях и ростках. Результаты представлены в таблице 3.

Как видно из представленных данных, в начале проращивания в корни и ростки попадает меньше белковых веществ, чем остается в эндосперме. Но по мере роста корней и ростков в них переходит все большее количество азотистых веществ. При этом у сорта пшеницы Приморская 39 до конца пятых суток солодоращения в корнях и ростках остается меньше азотистых веществ, чем в эндосперме и зародыше, а у сорта Приморская 40 количество белковых веществ в корнях начинает превышать количество азотистых веществ в эндосперме и зародыше на четвертые сутки солодоращения. Результаты показывают, что сорт пшеницы Приморская 40, изначально с более высоким уровнем белка в зерне, передает значительно больше азотсодержащих материалов в корни и ростки.

Таким образом, увеличивая время проращивания зерна, можно понижать содержание азотистых веществ в пшеничном солоде. Согласно литературным данным, изменяя время проращивания зерна, из пшеницы с высоким содержанием белка (16\%) удалось произвести солод хорошего качества [5]. С другой стороны, увеличение времени проращивания приводит к интенсивному росту ростков и корешков, что в конечном итоге увеличивает потери при солодоращении [1].

Результаты исследования показали, что у пшеницы с повышенным уровнем белка при проращивании зерна через корни и ростки теряется больше азотистых веществ по сравнению с пшеницей с низким содержанием белка. При увеличении времени проращивания потери азотистых веществ через корни и ростки увеличиваются не только за счет увеличения массы корней, но также за счет увеличения концентрации белковых веществ в корнях и ростках. С другой стороны, увеличение времени проращивания приводит к интенсивному росту ростков и корешков, что в конечном итоге увеличивает потери при солодоращении, а также увеличение времени солодоращения приводит к уменьшению массы зерна за счет потерь на дыхание, что, в свою очередь, способствует увеличению концентрации азотистых веществ в зерне. При подборе режима солодоращения следует учитывать обе тенденции. 


\section{Список литературы}

1. Кунце В. Технология солода и пива. СПб., 2009. 1064 с.

2. Depraetere S.A., Delvaux F., Coghe S., Delvaux F.R. Wheat variety and barley malt properties: influence on haze intensity and foam stability of wheat beer // J. Inst. Brew. 2004. Vol. 110, N3. Pp. 200-206.

3. Briggs D.E. Types of malt. Malt and Malting. Blackie Academic. London, 1998, pp. 723-726.

4. Нарцисс Л. Технология солодоращения : пер. с нем. 7-е изд., перераб. СПб., 2007. 582 с.

5. Jin Y.-H.,. Du J.-H,. Zhang K.-L,. Zhang X.-C. Effects of wheat starch contents on malt qualities // J. Inst. Brew. 2011. Vol. 117, N4. Pp. 534-540.

6. Delvaux F., Combes F.J., Delvaux F.R. The effect of wheat malting on the cooloidial haze of white beers // MBAA TQ. 2004. Vol. 41, N1. Pp. 27-32.

7. ГОСТ 5060-86. Ячмень пивоваренный. М., 1986.

8. Edney M.J., Legge W.G., Rossnagel B.G. Amino acid levels in wort and their significance in developing malting barley varieties $/ / 18^{\text {th }}$ North American barley researchers workshop and $4^{\text {th }}$ Canadian barley Symposium. Alberta, 2005. Pp. 104-107.

9. Leach R., Li Y., Edney M., Izydorczyk M., Egi A., Sawatzky K. Effects of barley endosperm texture, processing condition requirements and malt and beer quality // MBAA TQ. 2002. Vol. 39, N4. Pp. 191-202.

10. Jin Y., Zhang K.,. Du J. Effects of wheat protein content on endosperm composites and malt quality // J. Inst. Brew. 2008. Vol. 114, N4. Pp. 289-293.

11. Agu R.C. Some relationships between malted barleys of different nitrogen levels and the wort properties // J. Inst. Brew. 2003. Vol. 109, N2. Pp. 106-109.

12. Ростовская М.Ф., Загария С.Ю., Алябьев Б.А., Клыков А.Г. Пивоваренный солод из сортов пшеницы, возделываемых в Приморском крае // Пиво и напитки. 2009. №4. С. 36-38.

13. Briggs D.E. The biochemistry of malting. Malt and Malting. Blackie Academic, London, 1998. Pp. 133-218.

14. Булгаков Н.И. Биохимия солода и пива. М., 1976. 358 с.

15. Jin Y., Du J., Zhang K., Xie L., Li P. Relationship between Kolbach index and other quality parameters of wheat malt // J. Inst. Brew. 2012. Vol. 118, N1. Pp. 57-62. 
Rostovskaya M.F., Izvekova N.N., Alyabyev B.A, Prikhodko Y.V. DYNAMICS OF NITROGEN COMPOUNDS DURING MALTING PROCESS OF WHEAT WITH DIFFERENT PROTEIN LEVELS IN GRAIN

Far Eastern Federal University, School of biomedical, Sukhanova, 8, Vladivostok, 690950 (Russia), e-mail: rost-mf@mail.ru

The change in the content of nitrogenous substances in the process of malting grain of the two varieties of spring wheat (Triticum aestivum L.), grown in the Primorye Territory and containing differing levels of proteins in the grain was evaluated. It is shown that higher protein wheat transferred more nitrogen materials to the roots and shoots and this results to significant loss of nitrogen compounds in the endosperm and germ. Increase of germination term decreases the weight of grain due to loss of breath, which in turn increases the concentration of crude protein in the grain.

Keywords: wheat germination, nitrogenous compounds, protein, malt.

\section{References}

1. Kuntse V. Tekhnologiia soloda i piva. [Technology malt and beer]. St. Petersburg, 2009, 1064 p. (in Russ.).

2. Depraetere S.A., Delvaux F., Coghe S., Delvaux F.R. J. Inst. Brew., 2004, vol. 110, no. 3, pp. 200-206.

3. Briggs D.E. Types of malt. Malt and Malting. Blackie Academic. London, 1998, pp. 723-726.

4. Nartsiss L. Tekhnologiia solodorashcheniia. [Malting technology]. St. Petersburg, 2007, 582 p. (in Russ.).

5. Jin Y.-H.,. Du J.-H,. Zhang K.-L,. Zhang X.-C. J. Inst. Brew., 2011, vol. 117, no. 4, pp. 534-540.

6. Delvaux F., Combes F.J., Delvaux F.R. MBAA TQ., 2004, vol. 41, no. 1, pp. 27-32.

7. GOST 5060-86. Iachmen' pivovarennyi. [State Standard 5060-86. Brewing barley]. Moscow, 1986.

8. Edney M.J., Legge W.G., Rossnagel B.G. $18^{\text {th }}$ North American barley researchers workshop and $4^{\text {th }}$ Canadian barley Symposium. Alberta, 2005, pp. 104-107.

9. Leach R., Li Y., Edney M., Izydorczyk M., Egi A., Sawatzky K. MBAA TQ, 2002, vol. 39, no. 4, pp. 191-202.

10. Jin Y., Zhang K.,. Du J. J. Inst. Brew., 2008, vol. 114, no. 4, pp. 289-293.

11. Agu R.C. J. Inst. Brew., 2003, vol. 109, no. 2, pp. 106-109.

12. Rostovskaia M.F., Zagariia S.Iu., Aliab'ev B.A., Klykov A.G. Pivo i napitki, 2009, no. 4, pp. 36-38. (in Russ.).

13. Briggs D.E. The biochemistry of malting. Malt and Malting. Blackie Academic, London, 1998, pp. 133-218.

14. Bulgakov N.I. Biokhimiia soloda i piva. [Biochemistry malt and beer]. Moscow, 1976, 358 p. (in Russ.).

15. Jin Y., Du J., Zhang K., Xie L., Li P. J. Inst. Brew., 2012, vol. 118, no. 1, pp. 57-62.

\footnotetext{
* Corresponding author.
} 